\title{
Promotion of physical activities and healthy eating habits in Primary Care: maintenance of benefits
}

\author{
Promoção da atividade física e hábitos alimentares \\ saudáveis na Atenção Primária: \\ manutenção dos benefícios
}

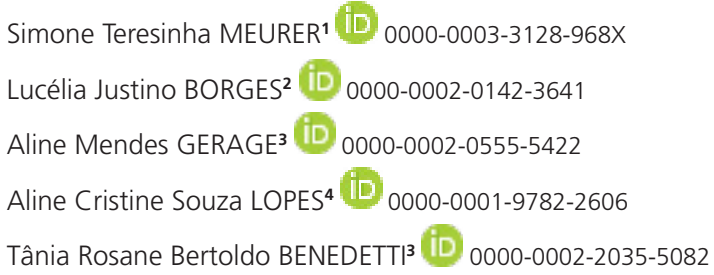

A B S T R A C T

\section{Objective}

To evaluate the maintenance of the beneficial effects of the Vida Ativa Melhorando a Saúde Program, six months after its completion.

1 Instituto Federal de Minas Gerais, Departamento de Formação Geral, Área de Educação Física. R. Mato Grosso, n. 2, Bairro Vista Alegre, 32407-190, Ibirité, MG, Brasil. Correspondence to: ST MEURER. E-mail: <simone.meurer@ifmg.edu.br>.

2 Universidade Federal do Paraná, Setor de Ciências Biológicas, Departamento de Educação Física. Curitiba, PR, Brasil.

3 Universidade Federal de Santa Catarina, Centro de Educação Física e Desportos, Programa de Pós-Graduação em Educação Física. Florianópolis, SC, Brasil.

${ }^{4}$ Universidade Federal de Minas Gerais, Escola de Enfermagem, Departamento de Nutrição. Belo Horizonte, MG, Brasil.

Support: Programa de Pesquisa para o Sistema Único de Saúde/Fundação de Amparo a Pesquisa do Estado de Santa Catarina (PPSUS, Research Program Single Health System/FAPESC, Santa Catarina State Research Support Foundation) (Process 2014/TR/2263) and the Conselho Nacional de Desenvolvimento Cientifico e Tecnológico (CNPq, Brazilian National Council for Scientific and Technological Development) (Process n. 14/2012 A. n. 475075/2012-9).

Article based on the dissertation of ST MEURER, entitled "Avaliação da estratégia de promoção de atividade física e alimentação saudável VAMOS: no Programa Academia da Saúde de Belo Horizonte, Minas Gerais”. Universidade Federal de Santa Catarina; 2016.

\section{How to cite this article}

Meure ST, Borges LJ, Gerage AL, Lopes ACS, Benedetti TRB. Promotion of physical activities and healthy eating habits in Primary Care: maintenance of benefits. Rev Nutr. 2020;33:e190120. https://doi.org/10.1590/1678-9865202033e190120 


\section{Methods}

A randomized controlled community trial was conducted in two poles of the Academia da Saúde Program, randomly identified as control or intervention groups. The study involved 291 adults and elderly involved in the routine activities of the Academia da Saúde Program. Individuals in the intervention group also participated to the Vida Ativa Melhorando a Saúde Program for 12 weeks. Accelerometers were used to evaluate physical activities, questionnaires for the evaluation of eating habits and anthropometric measures for nutritional status.

\section{Results}

Six months after completion of the intervention, the beneficial results obtained for physical activities and nutritional status were not maintained. The benefits related to eating habits remained, but not exclusively due to the effect of the intervention.

\section{Conclusion}

The Vida Ativa Melhorando a Saúde Program, in the applied format, was not able to promote lasting beneficial effects on physical activities and nutritional status. The Program is being restructured regarding the extension of the intervention time and its didactic material.

Keywords: Health promotion. Primary health care. Program evaluation.

\section{RE S U M O}

\section{Objetivo}

Avaliar a manutenção dos efeitos benéficos do programa Vida Ativa Melhorando a Saúde seis meses após a sua finalização.

\section{Métodos}

Foi conduzido um ensaio comunitário controlado e randomizado em dois polos do programa Academia da Saúde, identificados aleatoriamente como grupo controle e grupo intervenção. Participaram do estudo 291 adultos e idosos envolvidos nas atividades rotineiras do programa Academia da Saúde. Indivíduos do grupo intervenção participaram, adicionalmente, do programa Vida Ativa Melhorando a Saúde durante 12 semanas. Foram utilizados acelerômetros para avaliação da atividade física, questionários para a avaliação dos hábitos alimentares e medidas antropométricas para mensuração do estado nutricional.

\section{Resultados}

Seis meses após a finalização da intervenção, os resultados benéficos obtidos com a prática de atividade física e o estado nutricional não se mantiveram. Quanto aos hábitos alimentares, os benefícios se mantiveram, mas não foram exclusivamente pelo efeito da intervenção.

\section{Conclusão}

O programa Vida Ativa Melhorando a Saúde, no formato aplicado, não foi capaz de promover efeitos benéficos duradouros sobre a prática de atividade física e o estado nutricional dos indivíduos. O programa está sendo reformulado com a ampliação do tempo de intervenção e reestruturação do material didático.

Palavras-chave: Promoção da saúde. Atenção primária à saúde. Avaliação de projetos.

\section{NTRODUCTION}

The Programa Academia da Saúde (PAS, Health Academy Program) aims to contribute to the promotion and production of health care, as well as to the construction of healthy lifestyles by the population, acting as one of the Brazilian strategies to face Chronic Non-Communicable Diseases (NCDs) [1]. Actions related to the PAS, as long as they are articulated with the care network, favor the integrality of care through the establishment of bonds and co-responsibility regarding care, duly supported by health care services [2].

Studies show the potential of the PAS as a strategy for health promotion and care production in communities $[2,3]$. However, there are many challenges faced, such as the health profile of users 
and the maintenance of gains. In the city of Belo Horizonte, Brazil, where the PAS has been in place for more than 10 years, there was a high prevalence of NCDs [4,5], which, together with the high turnover of users [4], creates uncertainties regarding the continuity and quality of health care [5]. In view of this, the incorporation of new educational actions that promote empowerment and autonomy into the PAS program can enhance its positive results and favor the maintenance of selfcare [5].

The Programa Vida Ativa Melhorando a Saúde (VAMOS, Active Life Improving Health Program), an educational intervention addressed in this study, was developed and evaluated at the PAS of the city of Belo Horizonte, Brazil [5]. Previous studies have reported its effectiveness in increasing the daily minutes of moderate-vigorous Physical Activities (PA) and improving the diet of users $[5,6]$. The Program was also shown to be effective in eating habits, quality of life and cardiovascular risk variables in individuals living in the city of Recife, Brazil, and diagnosed with arterial hypertension [7]. However, these studies did not investigate the long-term maintenance of the benefits achieved, signaling an important knowledge gap, which this study intends to investigate.

In order to bring studies closer to reality, guide health policies and impact the population's health, it is necessary to understand the effects of an intervention beyond its effectiveness [8]. A recent study [9] showed an increase in the number of studies based on behavior change programs that address physical activities and/or healthy eating habits in Brazil. However, these studies are still focused on evaluating their effectiveness (88\%), and only $23 \%$ of them have evaluated the maintenance of benefits after their interruption [9].

In this sense, the objective was to evaluate the maintenance of the effects of the VAMOS Program, conducted in the context of the PAS of Belo Horizonte, six months after its completion.

\section{METHODS}

This article was based on the PhD thesis entitled "Evaluation of the Strategy for the Promotion of Physical Activity and Healthy Eating VAMOS: in the Health Academy Program of the city of Belo Horizonte (MG), Brazil". Further methodological details can be obtained from studies already published $[5,6]$.

The research is characterized as a controlled and randomized community trial in two poles of the Programa Academia da Saúde (Healthy Academy Program), in the city of Belo Horizonte, in the state of Minas Gerais, Brazil.

To improve comparability, the participant poles were defined according to the following parameters: recent implementation (at least two years prior to the moment of data collection, 2014); located in an area with the same Health Vulnerability Index ( $\mathrm{HVI})$ and in the same administrative region of the city. According to the parameters, three poles were eligible, all based in the northeast region of Belo Horizonte and with the same average $\mathrm{HVI}$. The pole for the development of the intervention (Intervention Group - IG) was randomly selected and so was the second pole, identified as the Control Group (CG).

The target population of this study were the frequent users of the premises ("assiduous", according to the PAS attendance lists) of the two selected poles, aged 20 or over, who agreed to voluntarily participate in the study. The research complied with the ethical precepts set and was approved by the Ethics Committee on Research with Human Beings of the State, Department of 
Health of the State of Santa Catarina (Opinion n. 767,704). All participants signed the Informed Consent Term.

The experimental design of the study is shown in Figure 1. During the intervention period, individuals from both groups (CG and IG) did their PAS physical and other routine activities as usual and, additionally, the IG participated in the VAMOS program for 12 consecutive weeks.

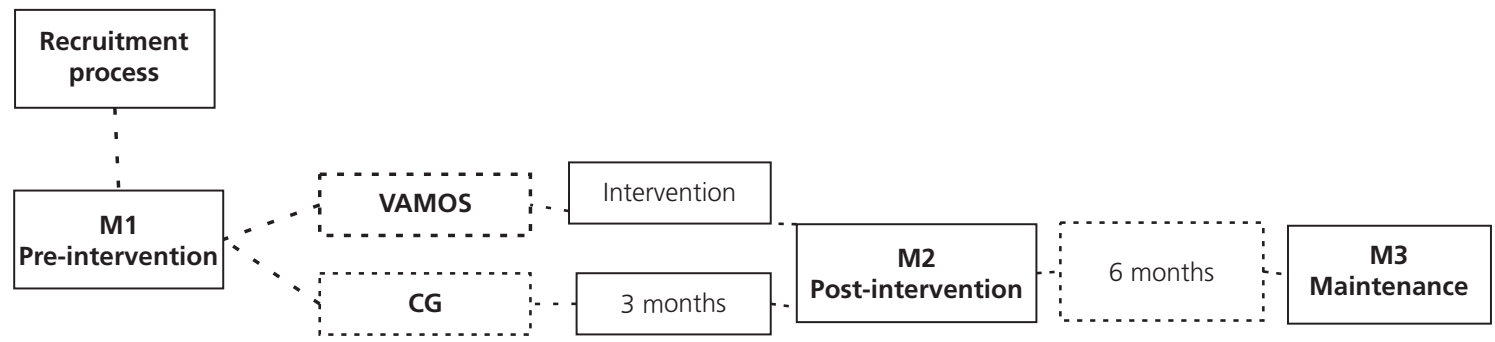

Figure 1. Study design. Belo Horizonte (MG), Brazil, 2015.

Note: CG: Control Group; M1: Moment 1; M2: Moment 2; M3: Moment 3; VAMOS: Vida Ativa Melhorando a Saúde.

The VAMOS Program aims to motivate people to adopt a healthy lifestyle, physical activities, and healthy eating habits, being guided by the Sociocognitive Theory [10]. The main theoretical constructs of behavior that this intervention focused on were: increasing self-efficacy and motivation, setting goals, self-monitoring, identifying social support, and developing solutions to overcoming barriers.

The physical activities approach was carried out from the perspective of an active lifestyle, encouraging participants to take advantage of different opportunities in their daily lives to add more movement. Food, on the other hand, was addressed based on the guidelines proposed by the Food Guide for the Brazilian Population [11]. The food groups - fresh and minimally processed, processed and ultra-processed foods - were presented, discussed, and analyzed, with the first group being identified as the main component for a healthier eating experience.

For the development of VAMOS, eight classes were organized with a maximum of 24 participants per class. Each had a weekly meeting of 60 minutes, for 12 consecutive weeks. At each meeting, a session of the didactic material was approached. The topics and objectives for each meeting have been published as supplementary material in Meurer et al. [6].

The VAMOS material was organized in booklets. An independent booklet was delivered in each session. All participants received their didactic material and a pedometer to assist in their self-monitoring and motivation to practice physical activities. The meetings were conducted by a previously trained Physical Education professional. The "conversation circles" was the methodology adopted.

Socioeconomic and demographic factors (age, sex, education, and per capita family income) were investigated; health profile (self-report for Chronic Non-Communicable Diseases, CNCDs); level of physical activity, food consumption and nutritional status. Actigraph accelerometers (GT3X and GT3X+) were used to assess the physical activity. Participants were instructed to use the equipment for seven consecutive days and should have at least four valid days (10 hours of daily recording), including a weekend day. Data were collected at a frequency of $30 \mathrm{~Hz}$, and the analysis was 
performed using 60-second epochs. The classification was made according to the cutoff points proposed by Sasaki et al. [12] for PA with mild intensities (100-2689counts/min) and Moderate and Vigorous (MVPA $\geq 2690$ counts/min). Values below 100counts/min were classified as time of sedentary behavior.

To evaluate food quality, the Food Frequency Questionnaire was used, referring to the average frequency of consumption in the last six months. The investigated foods were classified in two groups, following the guidelines of the Brazilian Food Guide [11]: fresh and minimally processed foods (raw vegetables and legumes, cooked vegetables and legumes, fruits, milk, meat, fish, and tubers/roots); and ultra-processed foods (sausages, sandwich cookies, sweets, fatty snacks/baked or fried savories, soda, powdered juice and industrialized condiments). Based on the report on the frequency of consumption of fresh, minimally processed and ultra-processed foods, a score was proposed. For fresh and minimally processed foods, the scores were as follows: daily consumption $=4$ points; weekly consumption $=3$ points; monthly consumption $=2$ points; rare consumption $=1$ point; zero consumption $=0$ points. For ultra-processed foods, the scores were inverted - daily consumption $=0$ points; weekly consumption $=1$ point; monthly consumption $=2$ points; rare consumption $=3$ points; zero consumption $=4$ points. In order to obtain the score value, the scores of the analyzed foods were summed up, which could vary from 0 to 60 points, and the higher the score, the greater the adequacy of the participant's diet.

From anthropometric measurements of height and Body Mass Index (BMI) was calculated (BMI=Body Mass $/$ Height $^{2}$ ). Different BMl classifications were adopted, for adults: $<18.5 \mathrm{~kg} / \mathrm{m}^{2}$, low weight; 18.5 to $24.9 \mathrm{~kg} / \mathrm{m}^{2}$, normal weight; 25 to $29.9 \mathrm{~kg} / \mathrm{m}^{2}$, overweight and $\geq 30 \mathrm{~kg} / \mathrm{m}^{2}$, obese [13]; and for the elderly: $<22 \mathrm{~kg} / \mathrm{m}^{2}$, low weight; 22 to $26.9 \mathrm{~kg} / \mathrm{m}^{2}$, normal weight; $\geq 27 \mathrm{Kg} / \mathrm{m}^{2}$, overweight [14].

All data were collected at the PAS poles, through face to face interviews, by nutrition students, nutritionists, and previously trained Physical Education professionals.

To assess the maintenance of the beneficial effects of the intervention, intra and intergroup comparisons of Moments 2 and 3 (M2 and M3) were performed for investigated outcomes. The Analysis of Covariance (ANCOVA) was performed for repeated measures, after confirming the normality of residues, with post hoc Least Significant Difference (LSD) test. The variables that showed significant differences between the participants of the CG and IG in the study's results in M1 were included as covariates.

Intent-to-treat analyzes were performed. Thus, all participants in Moment 1 (M1) were included in $\mathrm{M} 2$ and $\mathrm{M} 3$ of the study. In the case of missing values, the researchers opted for imputation, using the technique of replacing the missing value by the preceding one. Protocol analyzes were also conducted, including only data collected at different times. All the results obtained by protocol analyzes were similar to the results of intent-to-treat analyzes (data not shown).

\section{R E S U L T S}

Six months after the end of the intervention (M3), 211 users participated in the evaluations ( $C G=106 ; I G=105)$, representing $72.5 \%$ of the initial study sample $(211 / 291)$. Losses in M3 were related to infrequent users (suspended or dropouts) in the PAS, who were unable to attend the pole for reassessments or without an active phone line. There were also refusals to continue participating 
in the research ( $C G=7.5 \% ; \mathrm{IG}=7.8 \%)$. There were no significant differences in sociodemographic characteristics between the participants in the three moments of the study and those who only participated in M1 (data not shown).

Table 1 shows the socio-demographic and health data of the study participants. Differences were identified between participants in the CG and IG in terms of educational level and income (both higher among individuals in the IG).

In the evaluation of PA, it was identified that the time spent in moderate-vigorous PA, a variable that had significantly increased among participants of the IG in $M 2$, reduced statistically significantly in M3, without showing differences in relation to the CG (Table 2).

As for food consumption (Table 3), the benefits achieved after the intervention in the IG were maintained. However, in M3 of the study, the means of the general healthy eating score of the CG and IG did not differ from each other (Figure 2).

In assessing the maintenance of the VAMOS program, it was observed that there were no changes in the anthropometric variables from M2 to M3 (Table 3). In this assessment, there were no intra or intergroup differences (Group Effect: $p=0.09$ and $p=0.16$; Time Effect: $p=0.68$ and 0.67; Interaction Effect: $p=0.46$ and 0.44 for body weight and $\mathrm{BMI}$, respectively).

Table 1. Sociodemographic and health characteristics of the research participants in Moment 2 of the study, according to their distribution in the Control Group and Intervention Group. Belo Horizonte (MG), Brazil, 2015.

\begin{tabular}{|c|c|c|c|c|c|}
\hline Variables & \multicolumn{2}{|c|}{$C G(n=156)$} & \multicolumn{2}{|c|}{ IG $(n=135)$} & $\frac{p \text {-value }}{0.30^{2}}$ \\
\hline Female* & 139 & $89.1 \%$ & 125 & $92.6 \%$ & \\
\hline Male* & 17 & $10.9 \%$ & 10 & $7.4 \%$ & \\
\hline Age (years) ${ }^{* *}$ & 62 & $53-67$ & 62 & $55-68$ & $0.39^{1}$ \\
\hline Per capita monthly income $(\mathrm{BRL})^{\mathrm{f} * *}$ & 750.00 & $433-1000$ & 919.00 & $600-1400$ & $<0.01^{1+}$ \\
\hline Educational level (years) ${ }^{* *}$ & 4 & 04/ago & 11 & 05/dez & $<0.01^{1+}$ \\
\hline \multicolumn{6}{|l|}{ Referred morbidities } \\
\hline Diabetes* & 30 & $19.2 \%$ & 21 & $15.6 \%$ & $0.45^{2}$ \\
\hline Arterial hypertension* & 104 & $66.7 \%$ & 80 & $59.3 \%$ & $0.19^{2}$ \\
\hline Dyslipidemia* & 86 & $55.1 \%$ & 64 & $47.4 \%$ & $0.35^{2}$ \\
\hline
\end{tabular}

Note: 'Mann-Whitney Test; ${ }^{2}$ Chi-Square Test; ${ }^{\dagger}$ Values with statistical significance; ${ }^{\mathbf{E}}$ Undeclared cases $(\mathrm{n}=290) ;{ }^{*}$ Number and prevalence $(\%)$; ${ }^{* *}$ Median (P25-P75).

Table 2. Analysis of the maintenance of the usual practice of PAs of users of the Control Group and Intervention Group, six months after completion of the VAMOS program. Belo Horizonte (MG), Brazil, 2015.

\begin{tabular}{|c|c|c|c|c|c|c|c|}
\hline \multirow{2}{*}{ Variables } & \multicolumn{3}{|c|}{ Effect } & \multicolumn{2}{|c|}{$C G(n=143)$} & \multicolumn{2}{|c|}{$\mathrm{IG}(\mathrm{n}=117)$} \\
\hline & Time & Group & Interaction & M & SD & M & SD \\
\hline Time of sedentary behavior (min/day) & 0.39 & 0.41 & 0.60 & & & & \\
\hline $\begin{array}{l}\text { M2 } \\
\text { M3 }\end{array}$ & & & & $\begin{array}{l}380.32 \\
378.74\end{array}$ & $\begin{array}{l} \pm 99.3 \\
\pm 96.6\end{array}$ & $\begin{array}{l}389.41 \\
391.88\end{array}$ & $\begin{array}{l} \pm 96.4 \\
\pm 95.0\end{array}$ \\
\hline Light PA & 0.39 & 0.25 & 0.81 & & & & \\
\hline $\begin{array}{l}\text { M2 } \\
\text { M3 }\end{array}$ & & & & $\begin{array}{l}532.50 \\
534.82\end{array}$ & $\begin{array}{l} \pm 94.4 \\
\pm 92.0\end{array}$ & $\begin{array}{l}518.62 \\
519.17\end{array}$ & $\begin{array}{l} \pm 89.8 \\
\pm 91.9\end{array}$ \\
\hline Moderate-vigorous PA (min/day) & 0.71 & 0.11 & $0.03^{a}$ & & & & \\
\hline $\begin{array}{l}\text { M2 } \\
\text { M3 }\end{array}$ & & & & $\begin{array}{l}43.93 \\
46.17\end{array}$ & $\begin{array}{l} \pm 24.2 \\
\pm 23.4\end{array}$ & $\begin{array}{l}53.12 \\
49.46\end{array}$ & $\begin{array}{l} \pm 32.8 \\
\pm 32.3\end{array}$ \\
\hline
\end{tabular}

Note: aValues with statistical significance; Participants with valid accelerometer data M2: Moment 2; M3: Moment 3.

M: Median; SD: Standard Deviation. 
Table 3. Food consumption and nutritional status of the participants of the Control Group and Intervention Group, six months after completion of the VAMOS program. Belo Horizonte (MG), Brazil, 2015.

\begin{tabular}{|c|c|c|c|c|c|c|c|c|}
\hline \multirow{2}{*}{ Food } & \multicolumn{4}{|c|}{$C G(n=156)$} & \multicolumn{4}{|c|}{ IG $(n=135)$} \\
\hline & \multicolumn{2}{|c|}{ M2 } & \multicolumn{2}{|c|}{ M3 } & \multicolumn{2}{|c|}{ M2 } & \multicolumn{2}{|c|}{ M3 } \\
\hline Regular consumption* of fresh and minimally processed foods & \multicolumn{2}{|c|}{$\%$} & \multicolumn{2}{|c|}{$\%$} & \multicolumn{2}{|c|}{$\%$} & \multicolumn{2}{|c|}{$\%$} \\
\hline $\begin{array}{l}\text { Fruits } \\
\text { Raw legumes and vegetables } \\
\text { Cooked legumes and vegetables }\end{array}$ & \multirow{2}{*}{\multicolumn{2}{|c|}{$\begin{array}{l}71.8 \\
43.6 \\
49.4\end{array}$}} & \multicolumn{2}{|c|}{$\begin{array}{l}70.5 \\
55.1\end{array}$} & & & & $\begin{array}{l}4.1 \\
5.3 \\
3.1\end{array}$ \\
\hline \multicolumn{7}{|l|}{ Regular consumption* of ultra-processed foods } & & \\
\hline Sausages & \multicolumn{2}{|c|}{1.3} & \multicolumn{2}{|c|}{0.0} & \multicolumn{2}{|c|}{4.4} & \multicolumn{2}{|c|}{3.7} \\
\hline Fatty snacks / fried and bakes savories & \multicolumn{2}{|c|}{0.6} & \multicolumn{2}{|c|}{0.6} & \multicolumn{2}{|c|}{0.7} & \multicolumn{2}{|c|}{0.0} \\
\hline Sandwich cookies & \multirow{2}{*}{\multicolumn{2}{|c|}{$\begin{array}{r}1.3 \\
13.5\end{array}$}} & \multicolumn{2}{|c|}{0.6} & \multicolumn{2}{|c|}{1.5} & \multicolumn{2}{|c|}{0.7} \\
\hline Sweets & & & & & \multicolumn{2}{|c|}{14.8} & \multicolumn{2}{|c|}{13.3} \\
\hline Soda & \multicolumn{2}{|c|}{3.8} & \multicolumn{2}{|c|}{2.5} & \multirow{2}{*}{\multicolumn{2}{|c|}{$\begin{array}{l}3.7 \\
7.4\end{array}$}} & \multirow{2}{*}{\multicolumn{2}{|c|}{$\begin{array}{l}2.7 \\
3.7\end{array}$}} \\
\hline Powdered juice & \multicolumn{2}{|c|}{10.3} & \multicolumn{2}{|c|}{11.5} & & & & \\
\hline Industrialized condiments & \multicolumn{2}{|c|}{27.0} & & & & & & 4.8 \\
\hline Nutritional Status & M & SD & M & SD & M & SD & M & SD \\
\hline Body weight (Kg) & 68.8 & \pm 12.2 & 68.6 & \pm 12.2 & 70.1 & \pm 15.0 & 70.1 & \pm 15.2 \\
\hline $\mathrm{BMI}\left(\mathrm{Kg} / \mathrm{m}^{2}\right)$ & 28.4 & \pm 4.9 & 28.2 & \pm 4.9 & 28.6 & \pm 5.4 & 28.6 & \pm 5.5 \\
\hline
\end{tabular}

Note: "Regular consumption: weekly frequency equal to or greater than five times, following the classification used by Vigilância de Doenças Crônicas por Inquérito Telefônico. Ministério da Saúde (Brasil) [15]. M2: Moment 2; M3: Moment 3.

M: Median; SD: Standard Deviation.

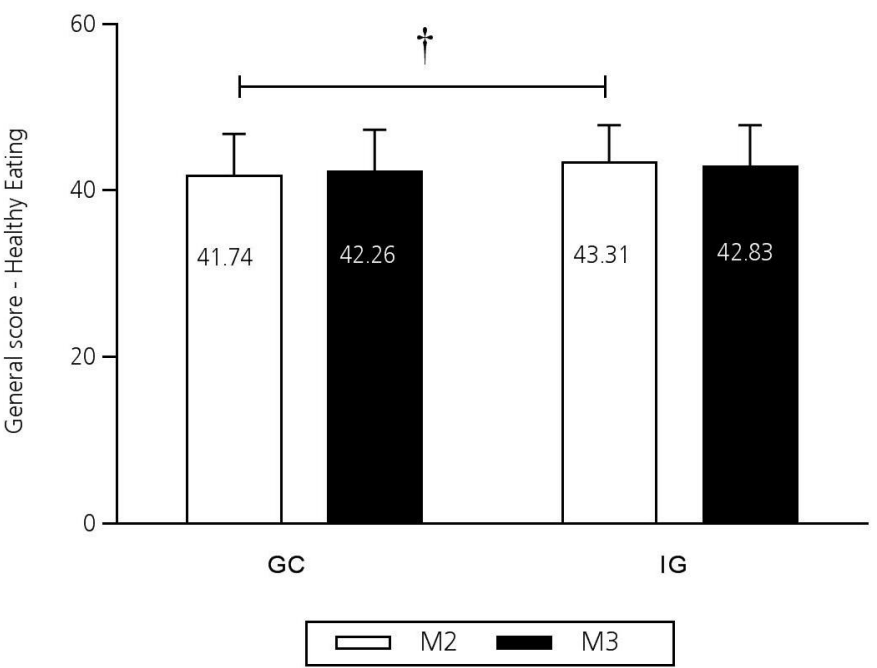

Figure 2. General healthy eating score for individuals in the Control Group and Intervention Group, six months after the completion of the VAMOS Program. Belo Horizonte (MG), Brazil, 2015.

Note: M2: Moment 2; M3: Moment $3 ;{ }^{\dagger} p \leq 0,05$ vs. GC.

\section{DISCUSSION}

The results indicate that, six months after the end of the intervention, the VAMOS Program was not able to promote the maintenance of the benefits achieved regarding PA and nutritional status. Regarding adequate and healthy food, it was observed that the benefits were maintained, however, this maintenance cannot be attributed exclusively to the intervention performed. 
There is a low frequency of reports of maintaining the positive effects of behavioral interventions with an emphasis on PA and/or healthy eating [9]. In a systematic review, involving 157 studies of interventions with similar primary (the same behaviors) [16], the frequency of individuals who reported the maintenance of benefits was 35\%. Thus, there are gaps in knowledge about the characteristics necessary for an intervention to have lasting effects after its interruption $[17,18]$.

It is believed that not addressing important issues for behavior change, such as those related to the environment, and the length of the intervention (three months), contributed to the nonmaintenance of positive effects six months after its end [19]. Effective and long-lasting interventions aimed at PA and eating habits lasted more than six months, used more than six behavioral strategies and included, as maintenance strategies, the prevention of relapses and rapid contacts after the completion of the main intervention [16], differing from this study.

Another review and meta-analysis study involving only healthy and physically inactive adults demonstrated that interventions were effective on the physical activity dimension and maintaining these changes after six months [20]. Behavior change was associated with the use of techniques such as action planning; instruction on how to perform the behavior; tips; practice of behavior and self-reward.

In addition, the studies included in the systematic reviews were conducted in developed countries that have socioeconomic and environmental conditions that favor the maintenance of healthier lifestyles $[16,20]$. In developing countries, such as Brazil, low educational, socioeconomic levels [21] and unfavorable environments contribute to explain the low prevalence of physical activities among the population [22]. Also, Salvo et al. [23] ratify the importance of positive environment perception for the practice of leisure-time physical activities among Brazilian adults. This speculation signals that an educational intervention like VAMOS has limitations in directing its actions, especially at intrapersonal level, and the influence of the environment on the behavior of PA is undeniable [24].

Another complementary explanation is the fact that it involves PAS users. Despite the statistically significant reduction in daily time in moderate and vigorous PA six months after the intervention, it is observed that the average minutes of daily PA meets health recommendations. It is believed that VAMOS may have brought extra motivation during the intervention and, after the end, the participants returned to their routine prior to the intervention for considering the time dedicated to PA as sufficient. One should also consider the importance of the PAS as a service for the production of care production and the promotion of health, which enabled the participants to maintain the level of physical activity which is appropriate for their health.

About food, six months after the end of the VAMOS intervention (M3), the users of the IG maintained the positive changes identified shortly after the end of the intervention (M2). However, when comparing the mean M3 scores between individuals the CG and the IG, the differences were not significant. Thus, the maintenance of these changes cannot be credited only to the performed intervention. The educational actions offered in the PAS may also have helped to maintain the benefits in the IG, as well as to improve food aspects among the individuals of the CG.

These results highlight the importance of health promotion interventions and actions to act in a complementary way in Primary Health Care (PHC) aiming to increase the effectiveness and maintenance of the positive results achieved [25]. In addition, to increase the impact of interventions, it is necessary to consider the influence of the social, economic, cultural, and environmental structure on health behaviors, aligning actions with public policies that promote access to adequate and healthy food. 
In relation to nutritional status, the intervention promoted changes in body weight only among overweight participants in M1 [6]. These results were not maintained in M3. It is believed that the intervention time may have been insufficient to maintain the identified improvements $[25,26]$. In addition, despite positive changes in their diet, such as increased consumption of raw vegetables and reduced consumption of ultra-processed foods [6], they probably had a low impact on the participants' caloric intake [27].

The study's limitations include the lack of environmental variables analysis that also intervene in long-term behavior change, as well as the differences in education and income of participants in the CG and IG. These differences impact, for example, their access to healthy food, the ability to understand health guidelines and access to adequate and safe spaces for PA. Another issue is the fact that the intervention was not conducted by health professionals who work in this service, but by one of the researchers, limiting inferences about maintenance of the effects. As positive aspects, it is worth mentioning the intervention in the PAS context, structured from consistent theoretical bases, the use of an objective measure to assess PA and the proposal of the general food score. Furthermore, the conduction of the intervention, according to the guidelines of the Food Guide for the Brazilian Population, ratifies its importance and applicability in the PAS.

\section{CONCLUSION}

The VAMOS Program, in the format developed in this investigation, was not able to promote the maintenance of benefits regarding PA and nutritional status. However, it was observed that the PA level of the participants remained adequate according to health recommendations, which highlights the importance of PAS as a health promotion service. Regarding adequate and healthy food, the benefits achieved were maintained, but they cannot be attributed exclusively to the intervention.

In order to increase the maintenance of results, VAMOS is being restructured, extending the intervention period, with new didactic materials and an online version. Still, to expand the positive results of VAMOS, it is understood that there is a need to align the intervention with macroenvironmental actions, in order to consider the social determinants for health promotion.

\section{A CKNOWLEDGEMENTS}

To the Belo Horizonte Municipal Health Department and the Physical Education professionals of the PAS units involved in the project.

CONTRIBUTORS

ST MEURER, ACS LOPES, and TRB BENEDETTI were responsible for the study conception and design, data analysis and interpretation. ST MEURER, LJ BORGES and AM Gerage were responsible for data analysis and interpretation, and writing this manuscript. All authors reviewed this study and approved the final version of the article.

\section{REFERENCES}

1. Malta DC, Oliveira TP, Santos MAS, Andrade SSCA, Silva MMA. Progress with the strategic action plan for tackling chronic non-communicable diseases in Brazil, 2011-2015. Epidemiol Serv Saúde. 2017;25:455-66. https://doi.org/10.5123/S1679-49742016000200016 
2. Sá GR, Dornelles GC, Cruz KG, Amorim RCA, Andrade SSCA, Oliveira TP, et al. O Programa Academia da Saúde como estratégia de promoção da saúde e modos de vida saudáveis: cenário nacional de implementação. Ciênc Saúde Coletiva. 2016;21(6):1849-60. https://doi.org/10.1590/1413-81232015216.09562016

3. Fernandes AP, Andrade ACS, Costa DAS, Dias MAS, Malta DC, Caiaffa WT. Programa Academias da Saúde e a promoção da atividade física na cidade: a experiência de Belo Horizonte, MG, Brasil. Ciênc Saúde Coletiva. 2017;22(12):3903-14. https://doi.org/10.1590/1413-812320172212.25282017

4. Mendonça RD, Horta PM, Santos LC, Lopes ACS. The dietary profile of socially vulnerable participants in health promotion programs in a Brazilian metropolis. Rev Bras Epidemiol. 2015;18(2):454-65. https://doi. org/10.1590/1980-5497201500020013

5. Meurer ST. Avaliação da estratégia de promoção de atividade física e alimentação saudável - VAMOS - no Programa Academia da Saúde de Belo Horizonte, Minas Gerais [tese]. Florianópolis: Universidade Federal de Santa Catarina; 2016.

6. Meurer ST, Lopes ACS, Almeida FA, Mendonça RD, Benedetti TRB. Effectiveness of the VAMOS Strategy for increasing physical activity and healthy dietary habits: a randomized controlled community trial. Health Educ Behav. 2019;46(3):406-16. https://doi.org/10.1177/1090198118820095

7. Gerage AM, Benedetti TRB, Ritti-Dias RM, Santos ACO, Souza BCC, Almeida FA. Effectiveness of a behavior change program on physical activity and eating habits in patients with hypertension: a randomized controlled trial. J Phys Act Health. 2017;14(12):943-52. https://doi.org/10.1123/jpah.2016-0268

8. Brito FA, Benedetti TRB, Tomicki C, Konrad LM, Sandreschi PF, Manta SW, Almeida FA. Tradução e adaptação do Check List RE-AIM para a realidade Brasileira. Rev Bras Ativ Fís Saúde. 2018;23:1-8. https://doi. org/10.12820/rbafs.23e0033

9. Konrad L, Tomicki C, Silva M, Almeida FA, Benedetti TB. Avaliação de programas de mudança de comportamento usando a ferramenta RE-AIM: um estudo de revisão sistemática. Rev Bras Ativ Fís Saúde. 2017;22(5):439-49. https://doi.org/10.12820/rbafs.v.22n5p439-449

10. Bandura A. Social foundations of thought and action: a social cognitive theory. Englenwood Cliffs: Prentice Hall; 1986.

11. Ministério da Saúde (Brasil). Guia Alimentar para a População Brasileira. 2nd ed. Brasília: Ministério; 2014.

12. Sasaki JE, John D, Freedson PS. Validation and comparison of ActiGraph activity monitors. J Sci Med Sport. 2011;14(5):411-6. https://doi.org/10.1016/j.jsams.2011.04.003

13. World Health Organization. Obesity: prevenig and managing the global epidemic. Geneva: Organization; 2000 .

14. American Dietetic Association. The Nutrition Screening Initiative: incorporating nutrition screening and interventions into medical practice: a monograph for physicians. Washington: American Academy of Family Physicians; 1994.

15. Ministério da Saúde (Brasil). VIGITEL Brasil 2014. Brasília: Ministério; 2015.

16. Fjeldsoe B, Neuhaus $M$, Winkler E, Eakin E. Systematic review of maintenance of behavior change following physical activity and dietary interventions. Health Psychol. 2011;30(1):99-109. https://doi.org/10.1037/ a0021974

17. Bellicha A, Kieusseian A, Fontvieille A-M, Tataranni A, Charreire $H$, Oppert J-M. Stair-use interventions in worksites and public settings: a systematic review of effectiveness and external validity. Prev Med. 2015;70:3-13. https://doi.org/10.1016/j.ypmed.2014.11.001

18. Grimmett C, Corbett T, Brunet J, Shepherd J, Pinto BM, May CR, et al. Systematic review and metaanalysis of maintenance of physical activity behaviour change in cancer survivors. Int J Behav Nutr Phys Act. 2019;16(37):1-20. https://doi.org/10.1186/s12966-019-0787-4

19. Ribeiro EHC, Garcia LMT, Salvador EP, Costa EF, Andrade DR, Latorre MRDO, et al. Assessment of the effectiveness of physical activity interventions in the Brazilian Unified Health System. Rev Saúde Pública. 2017; 51:1-12. https://doi.org/10.1590/s1518-8787.2017051006654

20. Howlett N, Trivedi D, Troop NA, Chater AM. Are physical activity interventions for healthy inactive adults effective in promoting behavior change and maintenance, and which behavior change techniques are effective? A systematic review and meta-analysis. Transl Behav Med. 2019;9:147-57. https://doi.org/10.1093/ tbm/iby010 
21. Silva KS, Del Duca GF, Garcia LM, Silva JA, Bertuol C, Oliveira ES et al. Barriers associated with frequency of leisure-time physical activity among Brazilian adults of different income strata. Scand J Med Sci Sport. 2019;26:206-13. https://doi.org/10.1111/sms.12419

22. Pitanga FJG, Almeida MCC, Queiroz CO, Aquino EML, Matos SMA. Physical activity in Brazil: lessons from ELSA-Brasil: narrative review. São Paulo Med J. 2017;135(4):391-5. https://dx.doi.org/10.1590/15163180.2017.0023190317

23. Salvo D, Reis RS, Hino AA, Hallal PC, Pratt M. Intensity-specific leisure-time physical activity and the built environment among Brazilian adults: a best-fit model. J Phys Act Health. 2015;12:307-18. https://doi. org/10.1123/jpah.2013-0087

24. Rech CR, Camargo EM, Araujo PAB, Loch MR, Reis RS. Perceived barriers to leisure-time physical activity in the Brazilian population. Rev Bras Med Esp. 2018;24(4):303-9. https://doi.org/10.1590/1517-869220 182404175052

25. Menezes MC, Mingoti SA, Cardoso CS, Mendonça RDD, Lopes ACS. Intervention based on Transtheoretical Model promotes anthropometric and nutritional improvements: a randomized controlled trial. Eat Behav. 2015;17:37-44. https://doi.org/10.1016/j.eatbeh.2014.12.007

26. Mendonça RD, Mingoti SA, Jaime PC, Lopes ACS. The impact of a nutritional intervention on the nutritional status and anthropometric profile of participants in the health Gym Programme in Brazil. Ciênc Saúde Coletiva. 2015;20(6):1937-46. https://doi.org/10.1590/1413-81232015206.11882014

27. Sichieri R, Bezerra IN, Araújo MC, Moura Souza A, Yokoo EM, Pereira RA. Major food sources contributing to energy intake - a nationwide survey of Brazilians aged 10 years and older. Br J Nutr. 2015;113(10):1638-42. https://doi.org/10.1017/S0007114515001075 